\title{
The effect of frequency of feeding on the utilization of free lysine by growing pigs
}

\author{
By E. S. BATTERHAM \\ School of Agriculture and Forestry, University of Melbourne, \\ Parkville, Victoria 3052, Australia
}

(Received I 5 May 1973 - Accepted I4 August I973)

\begin{abstract}
I. Pigs from 20 to $47 \mathrm{~kg}$ live weight were given a wheat-safflower diet supplemented with either 0,2 or $4 \mathrm{~g}$ L-lysine/ $/ \mathrm{kg}$ either once daily or in six equal portions at intervals of $3 \mathrm{~h}$.

2. The addition of lysine at both levels significantly $(P<0.00 \mathrm{I})$ increased growth rate, feed conversion and lean content of the ham.

3. Frequency of feeding had no effect on the response of pigs given the control diet.

4. A significant interaction $(P<0.05)$ between frequency of feeding and lysine supplementation occurred for growth rate. Growth responses to the supplements of 2 and $4 \mathrm{~g} \mathrm{L-lysine/}$ $\mathrm{kg}$ with once-daily feeding were only 43 and $69 \%$ of those achieved under the frequent-feeding regimen.
\end{abstract}

The effects of supplements of free lysine on the performance of pigs given cerealbased diets have been widely examined. Free lysine has been used as a supplement to dicts containing protein of poor-to-medium quality, or as a replacement for some of the protein concentrate. Recently lysine, and lysine together with combinations of other amino acids, have been used to replace protein concentrates completely (Braude, Mitchell, Myres, Newport \& Cuthbertson, 1972).

However, replacement of a portion of the feed lysine with free lysine has not necessarily resulted in a diet of similar nutritive value. Dent, English \& Raeburn (1970), when comparing least-cost formulated diets, observed that inferior pig performance resulted from the diets containing a high proportion of free lysine. The pigs in that study were given their rations twice daily and the authors speculated whether differential rates of absorption of the free and bound amino acids could have impaired utilization. The results of investigations in which the absorption of amino acids in the free and the bound form have been compared in rats have been variable. Gupta, Dakroury \& Harper (1958) and Rogers, Chen, Peraino \& Harper (1960) found that amino acids in intact protein could be digested and absorbed as quickly as those in the free form. In contrast, Rolls, Porter \& Westgarth (1972) found that free amino acids were generally absorbed more rapidly than those derived from protein. The actual absorption rates of protein-bound amino acids have been shown to vary and may be affected by the source of protein, its degree of processing, and the energy component of the diet (Gupta et al. 1958; Rogers et al. 1960; Goldberg \& Guggenheim, 1962; Buraczewski, Porter, Rolls \& Zebrowska, 1971). As a result Gupta et al. (1958) and Porter \& Rolls (1971) have emphasized that, unless similar rates of digestion and absorption of all sources of amino acids occur, the efficiency of utilization of the whole diet may be impaired. 
Table 1. Composition ( $\mathrm{g} / \mathrm{kg})$ of the diets

\begin{tabular}{|c|c|c|c|}
\hline Ingredient & Diet $\mathrm{I}$ & Diet 2 & Diet 3 \\
\hline $\begin{array}{l}\text { Wheat } \\
\text { Safflower meal }\end{array}$ & $\begin{array}{l}804^{\circ} 9 \\
160^{\circ} 0\end{array}$ & $\begin{array}{l}804 \cdot 9 \\
160 \cdot 0\end{array}$ & $\begin{array}{l}804-9 \\
160 \cdot 0\end{array}$ \\
\hline Minerals and vitamins & $30 \cdot 0$ & 30.0 & $30 \cdot 0$ \\
\hline L-Lysine hydrochloridet & $\cdots$ & $2 \cdot 5.5$ & $5 \cdot 10$ \\
\hline Starch & $5 \cdot 10$ & $2 \cdot 55$ & 一 \\
\hline
\end{tabular}

* Contributed per kg diy matter in diet: Fe $30 \mathrm{mg}, \mathrm{Zn} 100 \mathrm{mg}$, Mn $30 \mathrm{mg}, \mathrm{Cu} 5 \mathrm{mg}, \mathrm{I} 2 \mathrm{mg}$, Se $0.15 \mathrm{mg}$, salt $2.5 \mathrm{~g}$, retinol equivalent $960 \mu \mathrm{g}$, cholecalciferol $12 \mu \mathrm{g}, \alpha$-tocopherol equivalent $7 \mathrm{mg}$, thiamin I $\mathrm{mg}$, riboflavin $3 \mathrm{mg}$, nicotinic acid $24 \mathrm{mg}$, pantothenic acid $10 \mathrm{mg}$, pyridoxine $1.5 \mathrm{mg}$, cyanocobalamin $15 \mu \mathrm{g}$, pteroylmonoglutamic acid $2 \mathrm{mg}$, choline $500 \mathrm{mg}$, ascorbic acid Io $\mathrm{mg}$.

$\dagger$ L-Lysine monohydrochloride, anhydrous, $98 \%$ feed-grade, containing $78 \%$ L-lysine and manufactured by Kyowa Hakko Kogyo Co. Ltd, Japan.

If there was a differential rate of absorption between a free amino acid supplement and the basal diet, then the efficiency of utilization would be likely to be most affected if a single large meal was given daily and to decrease as the frequency of feeding increased. Such an effect would be particularly relevant to the use of lysine with pigs because in many countries they are fed once or twice daily. In the work described here, an experiment was made to examine the efficiency of utilization of free lysine when given to pigs fed once daily.

\section{EXPERIMEN'TAL}

\section{Diets and treatments}

Wheat and safflower were used as the basis of a diet deficient in lysine (Table I) but containing sufficient amounts of other amino acids to allow a growth response to the lysine supplement of approximately $20-30 \%$. This diet was then supplemented with either 2 or $4 \mathrm{~g}$ L-lysine $/ \mathrm{kg}$. The level of $2 \mathrm{~g} \mathrm{~L}-1 \mathrm{ysine} / \mathrm{kg}$ was chosen to observe the response to lysine under the two feeding regimens in conditions in which the full utilization of the added lysine should be obtained. The $4 \mathrm{~g} / \mathrm{kg}$ level of L-lysine was chosen to show that the diets supplemented with $2 \mathrm{~g} \mathrm{~L}$-lysine/ $/ \mathrm{kg}$ were in fact still lysine-deficient.

The three diets were given either once daily or in six equal portions. The once-daily feeding was at 08.00 hours and the six feeds were at 08.00 , I I.00, I4.00, I 7.00, 20.00 and 23.00 hours. Feeding at intervals of $3 \mathrm{~h}$ was chosen because Gupta et al. (1958) and Rogers et al. ( 1960 ) reported that approximately $50 \%$ of a given amount of food passed through the stomach in $3 \mathrm{~h}$, and thus by feeding at this frequency a reasonably constant flow of material for absorption should have been achieved.

The dietary ingredients (Table 2) were analysed by the following techniques: aciddetergent fibre (Drennan \& Maguire, I970), crude protein and diethyl ether extract (Association of Official Agricultural Chemists, 1965), tryptophan (Miller, 1967), cystine and cysteine (Jamalian \& Pellett, I968), available lysine (Roach, Sanderson \& Williams, I967), other amino acids (Spackman, Stein \& Moore, I958). The digestible energy of the control diet was determined with three pigs in metabolism crates, two collection periods being used. 
Table 2. Chemical composition of the ingredients and of the control diet

\begin{tabular}{|c|c|c|c|}
\hline & $\begin{array}{l}\text { Wheat } \\
(\mathrm{g} / \mathrm{kg})\end{array}$ & $\begin{array}{l}\text { Safflower } \\
(\mathrm{g} / \mathrm{kg})\end{array}$ & $\begin{array}{c}\text { Control diet* } \\
(\mathrm{g} / \mathrm{kg})\end{array}$ \\
\hline Crude protein & I 2 I & 507 & 179 \\
\hline Moisture & 120 & 87 & I I I \\
\hline Diethyl ether extract & 34 & I5 & 30 \\
\hline Acid-detergent fibre & 30 & 204 & 57 \\
\hline Amino acids & $(\mathrm{g} / \mathrm{I} 6 \mathrm{gN})$ & $(g / 16 g N)$ & $(\mathrm{g} / \mathrm{kg})$ \\
\hline Tryptophan & $x \cdot 07$ & $1 \cdot 22$ & $2 \cdot 0$ \\
\hline Lysine & $2 \cdot 5^{8}$ & $2 \cdot 94$ & $4^{\cdot 9} 9$ \\
\hline Available lysine & $2 \cdot 40$ & $2 \cdot 70$ & $4 \cdot 5$ \\
\hline Histidine & $2 \cdot 09$ & $2 \cdot 34$ & $3 \cdot 9$ \\
\hline Arginine & 4.25 & $8 \cdot 29$ & $10 \cdot 9$ \\
\hline Aspartic acid & 4.61 & $9 \cdot 96$ & $12 \cdot 6$ \\
\hline Threonine & $2 \cdot 77$ & $2 \cdot 91$ & $5 \cdot I$ \\
\hline Serine & $4 \cdot 56$ & $4 \cdot 22$ & $7 \cdot 9$ \\
\hline Glutamic acid & $28 \cdot 3^{8}$ & $19 \cdot 15$ & $43^{-2}$ \\
\hline Proline & $8 \cdot 55$ & $4: 42$ & I I 9 \\
\hline Glycine & $3 \cdot 84$ & $4 \cdot 85$ & $7 \cdot 7$ \\
\hline Alanine & $3 \cdot 30$ & 3.90 & $6 \cdot 4$ \\
\hline Cystine + cysteine & 2.07 & $\mathrm{I} \cdot 44$ & $3 \cdot 2$ \\
\hline Methionine & $x \cdot 24$ & $0.8 \mathrm{I}$ & $I \cdot 9$ \\
\hline Valine & 3.57 & $5 \cdot 25$ & $7 \cdot 7$ \\
\hline Isoleucine & $3 \cdot 32$ & 3.57 & $6 \cdot x$ \\
\hline Leucine & 5.90 & 5.66 & 10.3 \\
\hline Tyrosine & $2 \cdot 27$ & $2 \cdot 77$ & $4 \cdot 5$ \\
\hline Phenylalanine & $3 \cdot 90$ & $4 \cdot 37$ & $7 \cdot 3$ \\
\hline
\end{tabular}

\section{Animals and procedure}

The six dietary treatments were arranged in a $2 \times 3$ factorial design. There were eight replications, each consisting of six Large White or Large White $\partial \times$ Landrace $q$ pigs, which were selected and allotted to treatments on the basis of 7 -week weight, breed and sex. Four replications were females and four castrate males. The pigs were penned individually in a building maintained at a temperature of $22 \pm \mathrm{I}^{\circ}$. Water was supplied by nipple drinkers. The pigs were trained to consume approximately $1000 \mathrm{~g}$ of a starter diet in less than $\mathrm{I} h$ and the dietary treatments were introduced when the pigs reached $20 \mathrm{~kg}$ live weight.

The diets were offered at a daily rate of $1000 \mathrm{~g}$ at $20 \mathrm{~kg}$ live weight, increasing by $100 \mathrm{~g} / 2 \cdot 5 \mathrm{~kg}$ weight gain. The pigs were weighed weekly and rations were adjusted. The feed was offered dry with the frequent-feeding regimen but with the once-daily feeding system some water (approximately I part water to 3 parts feed) was added to the feed to help the pigs to consume their ration in $20-30 \mathrm{~min}$.

The pigs were slaughtered after reaching a minimum weight of $45 \mathrm{~kg}$. The ham was dissected and the percentage lean used as an indicator of carcass leanness. Pig response was assessed in terms of live-weight gain $/ \mathrm{d}$, food conversion ratio $(\mathrm{kg}$ food eaten $/ \mathrm{kg}$ live-weight gain) and percentage lean in the ham. The results were analysed statistically according to Snedecor \& Cochran (1967). 
Table 3. Effect of frequency of feeding on the utilization of free lysine by pigs during the 20-47 $\mathrm{kg}$ growth period

Feeding regimen

One feed/d

Control

+2 g L-lysine/kg diet

$+4 \mathrm{~g}$ L-lysine/kg diet

Six feeds/d

Control

+2 g L-lysine/kg dict

$+4 \mathrm{~g} \mathrm{~L}-1$ lysine $/ \mathrm{kg}$ diet

\section{Live-wt gain}

$(\mathrm{g} / \mathrm{d})$

$45 \mathrm{x}$

483

526

438

513

546

Statistical analyses $\uparrow$

Frequency of feeding

Control v. lysine

Interaction with frequency of feeding

2 g v. 4 g L-lysine/kg diet

Interaction with frequency of feeding

$\operatorname{SEM}(35 \mathrm{df}) t$

$\begin{array}{ccc}\text { NS } & \text { NS } & \text { NS } \\ * * * & * * * & * * * \\ * & \text { NS } & \text { NS } \\ * * * & * * & \text { NS } \\ \text { NS } & \text { NS } & \text { NS } \\ 9.4 & 0.052 & 6.1\end{array}$

* $\mathrm{kg}$ food eaten $/ \mathrm{kg}$ live-weight gain.

$\uparrow$ NS, not significant $(P>0.05) ; * P<0.05 ; * * P<0.01 ; * * * P<0.001$.

I $33 \mathrm{df}$ for lean in the ham, as two hams were misplaced at the abattoirs and missing values were used in the analysis.

\section{RESULTS}

The addition of lysine at both levels significantly $(P<0.00 \mathrm{I})$ increased growth rate, and percentage lean in the ham and reduced the feed-conversion ratio (Table 3 ).

Frequency of feeding had no effect on the response of pigs given the control diet. However, for weight gain, a significant interaction $(P<0.05)$ occurred betwcen frequency of feeding and lysine supplementation. Increased weight gains on dicts supplemented with 2 and $4 \mathrm{~g}$ L-lysine $/ \mathrm{kg}$ for the once-daily feeding routine wcre only 43 and $69 \%$ of those achieved with the frequent-feeding regimen.

Similarly, with the frequent-feeding regimen feed conversion ratio tended to be reduced and percentage lean in the ham tended to be increased but these effects did not reach statistical significance.

\section{DISCUSSION}

To cstimate the efficiency of utilization of lysine it is necessary to ensure that the supplemented diet is still lysine-deficient so that the supplementary lysine has been given the opportunity to be fully utilized, within the constraints of the feeding regimen . The increased response to the $\mathrm{L}$-lysine supplement at the $4 \mathrm{~g} / \mathrm{kg}$ level over that at the $2 \mathrm{~g} / \mathrm{kg}$ level for growth and food conversion efficiency with both feeding systems indicates that a comparison can be made at the $2 \mathrm{~g} / \mathrm{kg}$ level. Thus with once-daily feeding, free lysine was used with an efficiency of $43 \%$ relative to that with frequent feeding. Absolute utilization may have been less, as the utilization of the lysine with frequent feeding may not have been $100 \%$. A similar comparison cannot be made at 
the $4 \mathrm{~g} / \mathrm{kg}$ level since the apparent utilization of lysine of $69 \%$ appears to have been due to inefficient utilization of lysine at the $4 \mathrm{~g} / \mathrm{kg}$ level with frequent feeding (as a result of a surplus being provided) rather than to an increase in the efficiency of use of the extra increment of lysine with once-daily feeding. This is supported by the growth results, which show a rectilinear response to the increments of lysine for oncedaily feeding and a decreasing response for frequent feeding.

Addition of water to the feed was not necessary for the pigs fed six times daily as they were able to consume the small amounts of feed given without needing to drink. However, the addition of water to the feed of the pigs fed once daily helped the pigs to consume their rations quickly, since time was not wasted during feeding by the pigs going to the drinkers at the back of the pens. It seems unlikely that the results were affected by this addition of water, since there was no difference in the performance of pigs offered the control diet under the two feeding regimens.

The application of these results needs to be treated cautiously. It seems reasonable that absolute rates of absorption of free lysine will be similar with different batches of feed-grade lysine but the absorption rate of amino acids from the basal diets may vary, depending on other factors outlined on page 237 . However, lysine requirements based on the response of pigs to free lysine added to a diet at varying levels may be over-estimated if once-daily feeding is used. In practice, many experiments have been made with twice-daily feeding, but even here there may have been some over-estimation as the interval between the two feeds is usually $6 \mathrm{~h}$ or more. On the other hand, when feeding is ad lib. it is unlikely that utilization of the lysine will be affected.

The potential for the use of free lysine in diets for pigs is considerable (as it is for other non-ruminants) and it appears necessary that attempts be made to avoid ineffcient utilization. To attempt to compensate for the low utilization by increasing the amount of free lysine would seem both economically wasteful and potentially dangerous nutritionally, as it may lead to imbalances. A better approach would be to attempt to balance the arrival of the protein-bound amino acids and free lysine at the site of absorption. To achieve this by attempting to increase the rate of release of the protein-bound amino acids may be wasteful as it may oversaturate the utilization processes (Porter \& Rolls, 1971). Thus the answer is apparently to delay the rate of absorption of free lysine. This could be achieved by developing a slow-release lysine compound, by offering the lysine at a suitable interval of time after the basal diet, or by increasing the frequency of feeding. With pigs, a simple management solution may be to feed $a d l i b$. to $45 \mathrm{~kg}$, and then in restricted amounts to $80 \mathrm{~kg}$ live weight; the lysine supplement may be necessary only in the early growth stage, when the pig's requirement for lysine is greatest.

Grateful acknowledgements are made to Miss S. E. Ball, Miss R. Barnsley and Mrs H. Dickson for technical assistance; Mr S. Marshall for chemical analyses; Mr M. Fox, Victorian Department of Agriculture, for amino acid analyses; Mr G. O'Neil, New South Wales Department of Agriculture, for help with statistical analyses; Pacific Safflower Pty. Ltd, Sydney, for the safflower meal; Roche Products Pty. Ltd, Sydney, for the vitamin A; and to Mr A. C. Dunkin and Dr Nancy Millis for helpful 
advice. The salary of the author was paid by the New South Wales Department of Agriculture.

\section{REFERENCES}

Association of Official Agricultural Chemists (1965). Official Methods of Analysis. 1oth ed. Washington, DC: Association of Official Agricuitural Chemists.

Braude, R., Mitchell, K. G., Myres, A. W., Newport, M. J. \& Cuthbertson, A. (1972). Br. J. Nutr. 27, 169 .

Buraczewski, S., Porter, J. W. G., Rolls, B. A. \& Zebrowska, T. (I971). Br. F. Nutr. 25, 299.

Dent, J. B., English, P. R. \& Raeburn, J. R. (I970). Anim. Prod. 12, 379.

Drennan, P. \& Maguire, M. F. (1970). Ir. F. agric. Res, 9, 197.

Goldberg, A. \& Guggenheim, K. (1962). Biochem. \%. 83, 129.

Gupta, J. D., Dakroury, A. M. \& Harper, A. E. (I958). F. Nutr. 64, 447.

Jamalian, J. \& Pellett, P. L. (1968). F. Sci. Fd Agric. 19, 378.

Miller, E. L. (1967). F. Sci. Fd Agric. 18, 381.

Porter, J. W. G. \& Rolls, B. A. (1971). Proc. Nutr. Soc. 30, 17.

Roach, A. G., Sanderson, P. \& Williams, D. R. (1967). $\mathscr{~ . ~ S c i . ~ F d ~ A g r i c . ~ 1 8 , ~} 274$.

Rogers, Q. R., Chen, M.-L., Peraino, C. \& Harper, A. E. (1960). F. Nutr. 72, 331 .

Rolls, B. A., Porter, J. W. G. \& Westgarth, D. R. (r972). Br. F. Nutr. 28, 283.

Snedecor, G. W. \& Cochran, W. G. (1967). Statistical Methods 6th ed., p. 346. Ames, Iowa: Iowa State University Press.

Spackman, D. H., Stein, W. A. \& Moore, S. (1958). Analyt. Chem. 3o, r19o. 